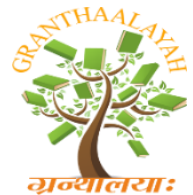

\author{
INTERNATIONAL JOURNAL OF RE
GRANTHAALAYAH \\ A knowledge Repository
}

Management

\title{
AFFECTING FACTORS TOWARD THE WILLINGNESS TO PRACTICE THE "ROOFTOP VEGETABLE GARDEN" OF THAINGUYEN CITIZENS
}

\author{
Pham Thi Minh Khuyen *1 \\ ${ }^{* 1}$ Industrial Economic Faculty, Thainguyen University of Technology
}

\begin{abstract}
With more care about safety of food in general and vegetable in special, the seriousness of air pollution in big city in Vietnam, citizens are now planting more fresh vegetables in their houses, especially in the rooftop. The research was carried on by personal interviews with 252 respondents in Thainguyen city, a big city in the Northeast area of Vietnam, to describe the situation and affecting factors toward the willingness to practice the "rooftop vegetable garden". The results of research show that only $33.7 \%$ respondents had high willingness to practice the "rooftop vegetable garden", however, there're up to $43.7 \%$ respondents who have "rooftop vegetable garden". Five factors have effects on practitioners' willingness to practice the "rooftop vegetable garden": 1. Urban environment pollution, 2. Urgency of fresh vegetable, 3. Knowledge about farming on the roof, 4. Time to practice and 5. Lifestyle. And three factors effects on non-practitioners' willingness to practice the "rooftop vegetable garden": 1 . Lack of knowledge about farming on the roof; 2. It is easier to buy than to grow fresh vegetables and 3. Lack of time.
\end{abstract}

Keywords: City Farming; Fresh Vegetable; Garden at Home; Willingness to Pay.

Cite This Article: Pham Thi Minh Khuyen. (2019). "AFFECTING FACTORS TOWARD THE WILLINGNESS TO PRACTICE THE "ROOFTOP VEGETABLE GARDEN" OF THAINGUYEN CITIZENS." International Journal of Research - Granthaalayah, 7(11), 96-105. https://doi.org/10.29121/granthaalayah.v7.i11.2020.337.

\section{Introduction}

Vegetables are the main food with increasing demand in Vietnam meals. According to Thai Nguyen Statistical Office (2019), the average vegetable consumption in Thainguyen city is $2.55 \mathrm{~kg} / \mathrm{month} /$ person, the city population is 364.078 people, therefore, every day the city consumes more than 30 tons of vegetables. And the supply from the city is not enough and often has to be imported from surrounding areas and other provinces.

With the emergence of more and more information about the unsafe process of producing and trading food especially vegetables on mass media and word of mouth information in Vietnam recently, customers nowadays take care more on finding safe vegetable resources and accept to pay more money for better vegetables. 
In addition, citizens nowadays have to face many health challenges that are directly influenced by urban environments: Industry, vehicle transports and the negative impact of impermeable concrete and asphalt surfaces. Many researches show that "rooftop garden" can reduce temperature and excessive heat energy absorption from solar radiation, thus resulting in a significant energy saving for air-conditioning in a building. Growing vegetable on rooftop also reduces the expenditure on purchase of vegetable from the market. It also provides minerals rich good quality fresh organic vegetable free from chemical, thus contributing to nutritional security (Vikash Kumar et al, 2019).

The research was carried on by personal interviews with 252 respondents in Thainguyen city, a big city in the Northeast area of Vietnam, to describe the situation and affecting factors toward the willingness to practice the "rooftop vegetable garden".

\section{Literature Review}

\section{1. "Green Roof" and "Rooftop Vegetable Garden"}

Many researches are found from 1990s about the development of "green roof" - a solution for problem of urbanization (problems of urban heat island and lack of greenery space and polluted environment, safe foods for citizens...).

The pioneers in developing the "green roof" are Germany (Rahman, S. R. and Ahmad, H., 2012). Since the 1880s, due to the safety problem to replace the highly flammable tar which was commonly used in roofs in Berlin, a German roofer, H. Koch developed a roofing technique by covering the tar with a layer of sand, gravel and then planting trees on the surface. The technique then was constructed throughout Berlin by fire resistance and low cost. Later in the 1960s, Reinhard Bornkamm, who then was called the father of modern green roofs, started studying the Koch's roof and built the first modern green roof project in Berlin on a building at the Free University where he combined extensive and intensive technologies in roof gardening (Rahman, S. R. and Ahmad, H., 2012).

In Asian region, the first roof garden in Tokyo was built in the Mitsukoshi roof in 1914. However, until 1939, the interest in modern green roof technology was really growing in Tokyo due to the urban heat island effect caused by World War II. The Japanese government nowadays is following Tokyo's lead on green roof legislation that requires houses and office buildings in urban areas should have at least $20 \%$ green of their rooftops (Rahman, S. R., Ahmad, H., 2012).

Nowadays, rooftop gardens are developed throughout the world and there are many famous rooftop gardens in HongKong (Hui, 2011), Italy (Science for Environment Policy, 2015), USA (Clarke, 2015), France (Carrot City, 2014),...However, "the development of green roof has not been implemented widely in Asia if compared to the western countries due to a lack of comprehensive research on how to suit the technology with our local climate especially in terms of the selection of suitable substrate and vegetation to be planted on the roof without incurring a high cost budget to build and maintain" (Rahman, S. R. and Ahmad, H., 2012).

There are many types of green roofs which are classified according to the type of plants, the size of planting, the manner of planting. Green roofs are roofs of buildings covered with a growth 
substrate and plants, which are also known as roof gardens, living roofs, and eco-roofs. Classified by depth of garden, we have: intensive garden with depth from 200 to $600 \mathrm{~mm}$; extensive garden with depth from 50 to $150 \mathrm{~mm}$ and semi - intensive garden with depth from 150 to $250 \mathrm{~mm}$ (Urbis Limited, 2007). Classified by method to plant we have: direct producing green roofs; rooftop container gardens; rooftop hydroponic systems (Vikash Kumar, 2019) or rooftop organic garden (Clarke, 2015).

The rooftop garden is a garden on the rooftop which covers with plants such as trees, shrubs, bushes and grasses. Similarly, when vegetables are grown on the rooftop, it is called "rooftop vegetable garden" (Vikash Kumar, 2019). Many vegetables and fruits can be grown in rooftop gardens: spices vegetables, lettuce, chicory, cabbage, tomato, aborigine, chili pepper, melon and watermelon,...

\subsection{Affecting Factors Toward the Willingness to Practice the "Rooftop Vegetable Garden"}

\section{Influence Factors to Practitioners}

Freisinger et al. (2015) listed some surrounding factors that affect toward the willingness to practice the rooftop garden as below:

- Building structure and urban density (Solitary or integrated location of the building; Need for climate-adaptive measures/green areas; Noise and air pollution)

- Legal aspects

- Socio-demographic structure (Population/social structure; Mindset/lifestyle; Income)

- Potential interference with the environment (Cooperative activities; Noise protection; Enhancing the quality of life; Spill-over effects)

- Social infrastructure and central facilities (Catering establishments, retailers, universities, administrative bodies, associations and schools)

- "Soft" location factors (The area's image; Urban living quality; Proportion of green areas; "Planning climate")

Ting Wang and Mathew Pryor (2019) found that the willingness to pay for social benefit of rooftop garden was related significantly to the degree of understanding of urban rooftop farming, level of education and income level. Most of the respondents who are willing to pay were from higher levels of understanding, higher levels of education as well as higher-income groups.

\section{Barriers Factors to Non-Practitioners}

Urbis Limited (2007) found the constraints or barriers against the development of green roofs (which apply in Hong Kong to differing degrees for intensive and extensive green roofs), may be considered to fall into four categories, each of which is briefly described below, namely: 1. Lack of knowledge and awareness; 2. Lack of incentive/ statutory mandate; 3. Economic constraints; 4. Lack of available roof area; and 5. Technical issues and risks associated with uncertainty.

MasturaSafayet et al. (2017) presented the practice and future prospect of rooftop farming in Dhaka city, the capital of Bangladesh, and also one of the most populated mega city in the world. They explored that, people in the city were only willing to bear minimum or moderate cost for practicing rooftop farming. Some main reasons why non-practitioners were not practicing rooftop 
farmingare: Lack of time to do the gardening (33.3\%); lack of proper farming knowledge (25\%). Some less common reasons are: It is easier to buy than to grow on their rooftop as it requires time, labor and money (19\%); having no manpower (15,5\%); do not have enough space $(7,2 \%)$.

The same factors were found in JhaRitesh Kumar (2019) research in Pokhara city (Nepan): lack of technical knowledge about farming on the roof, afraid of using soil as the media on their roof may create the problem of seepages in the roof and lack of leisure time to practice.

\section{Study Framework}

Basing on literature review, the framework in Figure 1 was developed to explore which factors affect to the willingness to practice the "rooftop vegetable garden" of Thainguyen citizens.

Ten factors have been hypothesized to influence the decision "yes" to practice the "rooftop vegetable garden": Urban environment pollution; Urgency of fresh vegetable; Knowledge about farming on the roof; Time to practice; Age; Income; Education Lifestyle; Legal aspects; Support Services;

And seven factors have been hypothesized to influence the decision "no" to practice the "rooftop vegetable garden": It is easier to buy than to grow fresh vegetables; Lack of space on the roof; Lack of time; Lack of manpower; Lack of knowledge about farming on the roof; Spend too much money; Problems with the roof (Seepages, Bugs,...).

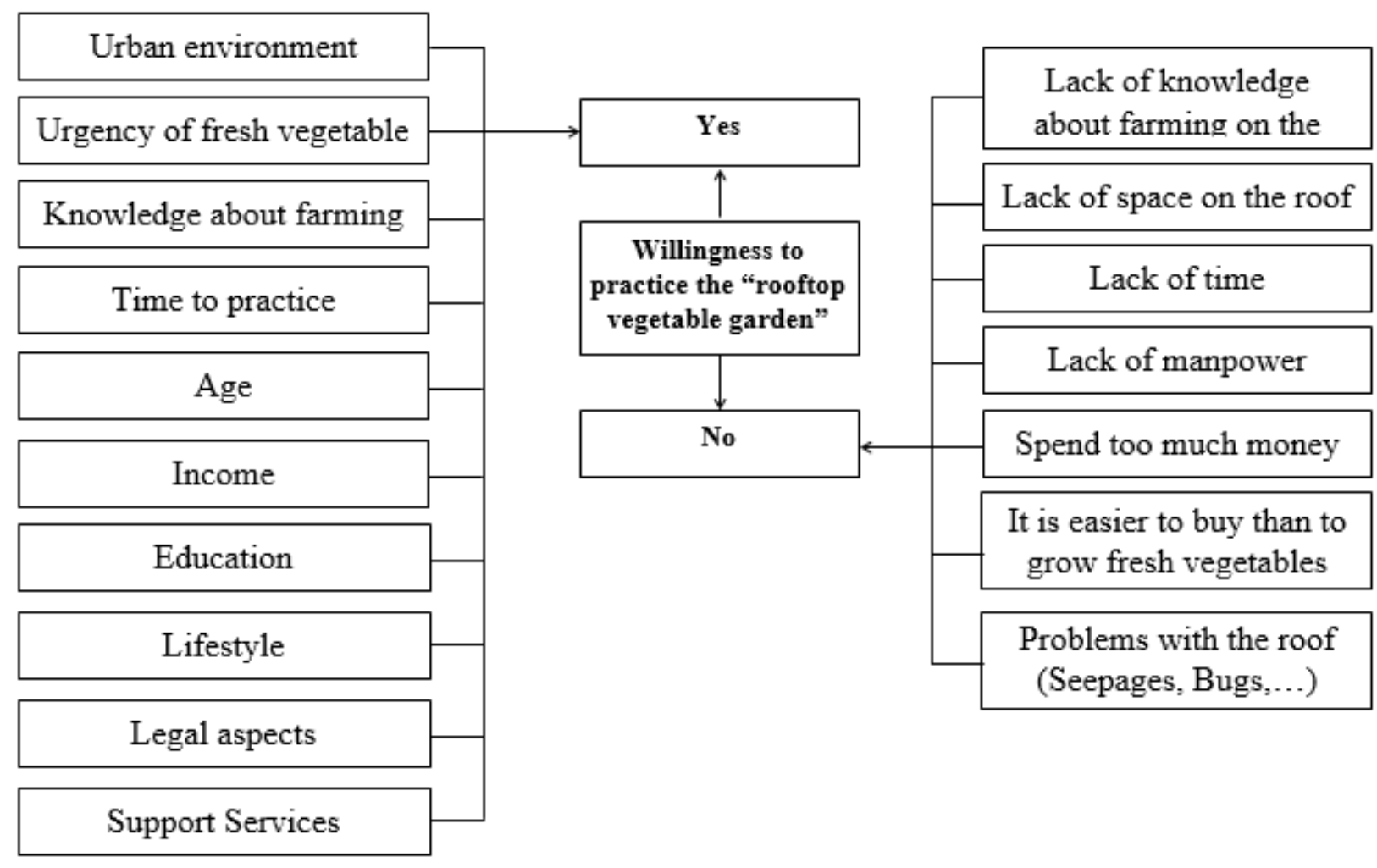

Figure 1: Affecting factors toward the willingness to practice the "rooftop vegetable garden" Source: Proposal of authors 


\section{Materials and Methods}

\section{Participants}

A survey was conducted in 4 big wards of Thai Nguyen City (Hoang Van Thu, Dong Quang, QuangTrung and PhanDinhPhung).

The selected sample in this survey was the primary responsible for preparing food for the families.

\section{Characteristics of Respondents}

The sample size was planned as 260 (65 samples in each wards), however, 8 respondents didn't have enough time to finish the questionnaires, so the real respondents number is 252 . Characteristics of respondents is described in Table 1.

The common age of respondents is from 25 to 60 years old, this is a group of married people and they are often the person in charge of buying food for the family. Most of them are women (81.3\%), married (81\%), this is also common situation in Vietnamese families in general and in Thai Nguyen city in particular, because women are the ones who often take care of their family meals. The most common number of family members is 4 (usually with 2 generations, with parents and 2 children), a popular family model in Vietnam. Families with more than 4 members and 2 generation also still accounts for a large proportion $(44.4 \%)$.

Table1: Characteristics of respondents

\begin{tabular}{|l|l|l|l|l|l|}
\hline Age & No & $\mathbf{\%}$ & Gender & No & $\%$ \\
\hline Below 25 years old & 33 & 13,1 & Male & 47 & 18,7 \\
\hline From 25 to 40 years old & 97 & 38,5 & Female & 205 & 81,3 \\
\hline From 41 to 60 years old & 73 & 29,0 & Total & 252 & 100 \\
\hline Above 60 years old & 49 & 19,4 & Number of family members \\
\hline Total & 252 & 100 & 2 & 18 & 7,1 \\
\hline Marital status & & & 3 & 21 & 8,3 \\
\hline Divorced & 7 & 2,8 & 4 & 101 & 40,2 \\
\hline Married & 204 & 81,0 & 5 & 44 & 17,5 \\
\hline Single & 41 & 16,2 & 6 & 48 & 19,0 \\
\hline Total & 252 & 100 & Above 6 & 20 & 7,9 \\
\hline & & & Total & 252 & 100 \\
\hline
\end{tabular}

Source: Research results in 2018.

\section{Data Gathering}

Preliminary information about the affecting factors toward the willingness to practice the "rooftop vegetable garden" was collected through direct personal interviews at the respondents' houses. A group of 4 students from the Thainguyen University of Technology were trained to do the survey with prepared questionnaires and encode the information to SPSS software.

\section{Instruments}

Semi - Structural questionnaire (with three main parts) was used as the main instruments of the survey: 
The first part gathered information on the respondent's personal profile: age, gender, marital status, number of family members, etc.

The second part gathered information on their willingness and situation to practice the "rooftop vegetable garden". The willingness to practice the "rooftop vegetable garden" is measured on a 5level scale: 1 . Definitely not do (0\%-19\%); 2 . Almost certainly not do (20\%-40\%); 3. Maybe do - Maybe not do (41\% - 60\%); 4. Almost certainly do (61\%-80\%); 5. Definitely do (81\%-100\%). The situation to practice the "rooftop vegetable garden" is measured on 3-level scale: 1. Have "Rooftop vegetable garden"; 2. Don't have, but want to have; 3. Don't want to have

The third part gathered information on factors affected on their willingness. The respondents were divided to 2 groups: group 1 included people with roof gardening practices(practitioners) and group 2 included people with no roof gardening practices(non-practitioners).

\section{Data Processing}

After being reviewed, information on questionnaires will be encoded and entered data into SPSS 22.0 software.

\section{Data Analyzing}

The Descriptive statistics and Multiple Linear Regressions methodwas usedto describe the information on respondent's personal profileand their willingness to practice the "rooftop vegetable garden" and to specify the effect of the factors to the respondents' willingness to practice the "rooftop vegetable garden".

\section{Results and Discussions}

\subsection{Willingness and situation to practice the "rooftop vegetable garden"}

$29 \%$ respondents definitely don't practice and almost certainly don't practice the "Rooftop vegetable garden" and they also don't have any "Rooftop vegetable garden".

A bit higher ratio respondents definitely practice and almost certainly practice the "Rooftop vegetable garden" (33.7\%) and almost of them actually have their "Rooftop vegetable garden". Among respondents who are neutral (37.3\%), there are only $10.7 \%$ respondents actually have their "Rooftop vegetable garden".

Table 2: Willingness and situation to practice the "Rooftop vegetable garden"

\begin{tabular}{|c|c|c|c|c|c|}
\hline \multirow{3}{*}{$\begin{array}{l}\text { Willingness to practice "Rooftop vegetable } \\
\text { garden"? }\end{array}$} & \multicolumn{5}{|c|}{ Have "Rooftop vegetable garden"? } \\
\hline & \multicolumn{2}{|c|}{ Total } & \multirow{2}{*}{$\begin{array}{c}\text { Yes, I } \\
\text { do }\end{array}$} & \multirow{2}{*}{$\begin{array}{l}\text { No, But I want } \\
\text { to do }\end{array}$} & \multirow{2}{*}{$\begin{array}{l}\text { No, I don't want } \\
\text { to do }\end{array}$} \\
\hline & Frequency & Percent & & & \\
\hline Definitely not do & 33 & 13.1 & 0 & 11 & 22 \\
\hline Almost certainly not do & 40 & 15.9 & 0 & 20 & 20 \\
\hline Maybe do - Maybe not do & 94 & 37.3 & 27 & 53 & 14 \\
\hline Almost certainly do & 50 & 19.8 & 48 & 2 & 0 \\
\hline Definitely do & 35 & 13.9 & 35 & 0 & 0 \\
\hline Total & 252 & 100 & 110 & 86 & 56 \\
\hline
\end{tabular}

Source: Research results in 2018. 
43,7\% respondents have "Rooftop vegetable garden"is high ratio, but, almost of them practice Rooftop container gardens $(76.4 \%)$ with small space $\left(62,7 \%\right.$ below $\left.10 \mathrm{~m}^{2}\right)$ and grow only herbs and seasonal vegetables that are easy to grow $(70 \%)$.

\subsection{Affecting factors toward the willingness to practice the "rooftop vegetable garden"} Influence factors toward the willingness to practice the "rooftop vegetable garden" of practitioners

Results of the study with 110 practitioners showed that, with a statistical significance of $5 \%$ (sig. <0.05), only five factors have effects on their willingness to practice the "rooftop vegetable garden" (Table 3): Urban environment pollution (sig. = 0.026), Urgency of fresh vegetable $(\mathrm{sig} .=0.015)$, Knowledge about farming on the roof (sig.=0.013), Time to practice (sig.=0.033) and Lifestyle (sig.=0.012). The results are rather same as results of Freisinger et al. (2015) and Ting Wang \& Mathew Pryor (2019).

In which, four factors: Urban environment pollution, Urgency of fresh vegetable, Knowledge about farming on the roof and Lifestyle, have positive effects on practitioners' willingness to practice the "rooftop vegetable garden" ( $B$ and Beta $>0)$. Only "Time to practice" factor has negative effects on practitioners' willingness to practice the "rooftop vegetable garden" ( $B$ and Beta<0). This result is consistent with the fact that citizens nowadays are busier with little free time, so the greater the time element's influence, the lower willingness to practice the "rooftop vegetables garden" citizens will have.

Table 3: Influence factors toward the willingness to practice the "rooftop vegetable garden" of practitioners

\begin{tabular}{|c|c|c|c|c|c|c|}
\hline \multirow{2}{*}{\multicolumn{2}{|c|}{ Model }} & \multicolumn{2}{|c|}{$\begin{array}{l}\text { Unstandardized } \\
\text { Coefficients }\end{array}$} & \multirow{2}{*}{$\begin{array}{c}\begin{array}{c}\text { Standardized } \\
\text { Coefficients }\end{array} \\
\text { Beta }\end{array}$} & \multirow[t]{2}{*}{$\mathbf{T}$} & \multirow[t]{2}{*}{ Sig. } \\
\hline & & B & Std. Error & & & \\
\hline \multirow[t]{11}{*}{1} & (Constant) & .434 & .508 & & .854 & .395 \\
\hline & $\begin{array}{l}\text { Urban environment } \\
\text { pollution }\end{array}$ & .245 & .108 & .240 & 2.261 & .026 \\
\hline & $\begin{array}{l}\text { Urgency of } \\
\text { vegetable }\end{array}$ fresh & .338 & .136 & .279 & 2.487 & .015 \\
\hline & $\begin{array}{l}\text { Knowledge about } \\
\text { farming on the roof }\end{array}$ & .262 & .103 & .258 & 2.535 & .013 \\
\hline & Time to practice & -.163 & .076 & -.154 & -2.159 & .033 \\
\hline & Age & .034 & .065 & .039 & .520 & .604 \\
\hline & Income & .007 & .064 & .008 & .106 & .916 \\
\hline & Education & .074 & .072 & .088 & 1.022 & .309 \\
\hline & Lifestyle & .197 & .077 & .194 & 2.561 & .012 \\
\hline & Legal aspects & -.093 & .094 & -.088 & -.993 & .323 \\
\hline & Support Services & .046 & .075 & .052 & .613 & .542 \\
\hline \multicolumn{7}{|c|}{$\mathrm{R} 2=0,588$} \\
\hline \multicolumn{7}{|c|}{$\mathrm{F}(\mathrm{ANOVA})=14.151$} \\
\hline
\end{tabular}


$\operatorname{Sig}($ ANOVA $)=0,000$

Dependent Variable: Willingness to practice "Rooftop vegetable garden"

Predictors: (Constant), Support Services, Income, Urban environment pollution, Time to practice, Age, Lifestyle, Education, Legal aspects, Knowledge about farming on the roof , Urgency of fresh vegetable

Source: Research results in 2018.

\subsection{Barriers factors toward the willingness to practice the "rooftop vegetable garden" of non-practitioners}

Results of the study with 142 non-practitioners showed that, with a statistical significance of 5\% (sig. <0.05), three factors have negative effects on their willingness to practice the "rooftop vegetable garden" of non-practitioners(Table 4): It is easier to buy than to grow fresh vegetables (sig. = 0.000), Lack of time (sig.=0.007), Lack of knowledge about farming on the roof (sig.=0.000). That situation means that the easier to buy than to grow fresh vegetables; the less of time to practice and the less knowledge about farming on the roof of the respondents, the lower willingness to practice the "rooftop vegetables garden" they will have.

Table 4: Barriers factors toward the willingness to practice the "rooftop vegetable garden" of non-practitioners

\begin{tabular}{|c|c|c|c|c|c|c|}
\hline \multirow{2}{*}{\multicolumn{2}{|c|}{ Model }} & \multicolumn{2}{|c|}{$\begin{array}{l}\text { Unstandardized } \\
\text { Coefficients }\end{array}$} & \multirow{3}{*}{$\begin{array}{c}\begin{array}{c}\text { Standardized } \\
\text { Coefficients }\end{array} \\
\text { Beta } \\
\end{array}$} & \multirow[t]{2}{*}{$\mathbf{T}$} & \multirow[t]{2}{*}{ Sig. } \\
\hline & & B & Std. Error & & & \\
\hline \multirow[t]{8}{*}{1} & (Constant) & 4,801 & ,270 & & 17,752 & ,000 \\
\hline & $\begin{array}{l}\text { It is easier to buy than to } \\
\text { grow fresh vegetables }\end{array}$ &,- 310 &, 054 &,- 373 & $-5,733$ & ,000 \\
\hline & $\begin{array}{l}\text { Lack of space on the } \\
\text { roof }\end{array}$ & ,021 & ,092 & ,018 & ,234 & ,815 \\
\hline & Lack of time &,- 245 & ,089 &,- 284 & $-2,746$ & ,007 \\
\hline & Lack of manpower &, 102 & 105 &, 114 & 971 & ,334 \\
\hline & $\begin{array}{l}\text { Lack of knowledge } \\
\text { about farming on the } \\
\text { roof }\end{array}$ &,- 391 &, 082 &,- 441 & $-4,760$ & ,000 \\
\hline & Spend too much money &,- 047 & 079 &,- 045 &,- 593 & ,554 \\
\hline & $\begin{array}{l}\text { Problems with the roof } \\
(\text { Seepages, Bugs,...) }\end{array}$ &, 111 & , 080 &, 121 & 1,399 &, 164 \\
\hline \multicolumn{7}{|c|}{$\mathrm{R} 2=0,550$} \\
\hline \multicolumn{7}{|c|}{$\mathrm{F}(\mathrm{ANOVA})=23.351$} \\
\hline \multicolumn{7}{|c|}{$\operatorname{Sig}(\mathrm{ANOVA})=0,000$} \\
\hline \multicolumn{7}{|c|}{ Dependent Variable: Willingness to practice "Rooftop vegetable garden" } \\
\hline \multicolumn{7}{|c|}{$\begin{array}{l}\text { Predictors: (Constant), Problems with the roof (Seepages, Bugs,...), It is easier to buy than to } \\
\text { grow fresh vegetables, Lack of time, Lack of space on the roof, Spend too much money, Lack } \\
\text { of knowledge about farming on the roof, Lack of manpower }\end{array}$} \\
\hline
\end{tabular}

Source: Research results in 2018. 


\section{Conclusions and Recommendations}

The results of research show that only $33.7 \%$ respondents had high willingness to practice the "rooftop vegetable garden", however, there're up to $43.7 \%$ respondents who have "rooftop vegetable garden". This situation means that Thainguyen citizens nowadays care more about their health, especially about their foods and living environment. Therefore, in the future, Thainguyen city can be potential market for seeds, materials and rooftop vegetable farming services.

When studying on affecting factors toward the willingness to practice the rooftop garden of Thainguyencitizens, researchers find out that, some factors often have positive influence while some others often have negative factors. Five factors have effects on practitioners' willingness to practice the "rooftop vegetable garden": 1. Urban environment pollution, 2. Urgency of fresh vegetable, 3. Knowledge about farming on the roof, 4. Time to practice and 5. Lifestyle. While non-practitioners were negative affected by three factors: 1 . Lack of knowledge about farming on the roof; 2. It is easier to buy than to grow fresh vegetables and 3. Lack of time.

\section{Acknowledgements}

Authors would like to express our special thanks to Thainguyen University of Technology for giving us the permission to use all required equipment and the necessary fund to complete the article.

\section{References}

[1] Thai Nguyen Statistical Office, Thai Nguyen Statistical Yearbook 2018, 2019.

[2] VikashKuma et al. (2019), Rooftop Vegetable Garden- A new concept of urban agriculture, AGRICULTURE \& FOOD: e-Newsletter, Volume 1 - Issue 4 - April 2012, 109-112.

[3] Rahman, S. R. and Ahmad, H. (2012). Green roofs as urban antidote: A review on aesthetic environmental, economic and social benefits. South East Asia Technical University Conference Proceeding, 6, $93-97$

[4] Hui, D.C. (2011). Green roof urban farming for buildings in high-density urban cities. the Hainan China World Green Roof Conference, pp. 1-9. China.

[5] Science for Environment Policy (2015). March 26. Rooftop gardens could grow three quarters of city's vegetables. Retrieved February 9, 2016, from ec.europa.eu: 〈http://ec.europa.eu/ environment/integration/research/newsalert/pdf/rooftop_gardens_could_grow_three_quarters_of_ citys_vegetables_409na2_en.pdf $\rangle$.

[6] Clarke, P. (2015). The World's Largest Rooftop Farm Sets the Stage for Urban Growth. Retrieved February 9, 2016, from waldenlabs.com:〈http://waldenlabs.com/worlds-largest-rooftop-farm/〉 .

[7] Carrot City (2014). Lufa Farms / FermesLufa. Retrieved February 7, 2016, from ryerson.ca: http://www.ryerson.ca/carrotcity/board_pages/rooftops/lufa_farms.html.

[8] Urbis Limited, Study on Green Roof Application in Hong Kong, Final Report, Architectural Services Department, Hong Kong, 2007, 22-25.

[9] Freisinger, U. B.; Specht, K.; Sawicka, M.; Busse, M.; Siebert, R.; Werner, A.; Thomaier, S.; Henckel, D.; Galda, A.; Dierich, A.; Wurbs, S.; Grosse-Heitmeyer, J.; Schön, S.; Walk, H., There ‘s something growing on the roof. Rooftop greenhouses. Idea, Planning, Implementation. Leibniz Centre for Agricultural Landscape Research (ZALF), Müncheberg, 2015.

[10] Ting Wang and Mathew Pryor, Social Value of Urban Rooftop Farming: A Hong Kong Case Study, Agricultural Economics - Current Issues, 2019. Surendra N. Kulshreshtha, IntechOpen, DOI: 
10.5772/intechopen.89279. Available from: https://www.intechopen.com/books/agriculturaleconomics-current-issues/social-value-of-urban-rooftop-farming-a-hong-kong-case-study.

[11] MasturaSafayet, Md. FaqrulArefin, Md. MuslehUddinHasan, Present practice and future prospect of rooftop farming in Dhaka city: A step towards urban sustainability, Journal of Urban Management, Volume 6, Issue 2, December 2017, 56-65. https://doi.org/10.1016/ j.jum.2017.12.001.

[12] JhaRitesh Kumar, Bhattarai Natasha, KC Suraj, ShresthaArjun Kumar, KadariyaManahar, Rooftop Farming: An Alternative To Conventional Farming For Urban Sustainability. Malaysian Journal of Sustainable Agriculture, 3(1), 2019, 39-43

\footnotetext{
*Corresponding author.

E-mail address: khuyenqlen @ gmail.com
} 